\title{
Erosion-deposition patterns and
}

depo-center movements in branching

channels at the near-estuary reach of

the Yangtze River

Zhu, B

http://hdl.handle.net/10026.1/17654

10.1007/s11707-019-0808-2

Frontiers of Earth Science

Springer Science and Business Media LLC

All content in PEARL is protected by copyright law. Author manuscripts are made available in accordance with publisher policies. Please cite only the published version using the details provided on the item record or document. In the absence of an open licence (e.g. Creative Commons), permissions for further reuse of content should be sought from the publisher or author. 


\section{Erosion-deposition patterns and depo-center movements in} branching channels at the near-estuary reach of the Yangtze River

Boyuan ZHU (凶) ${ }^{1}$, Jinyun DENG ${ }^{2}$, Jinwu TANG ${ }^{3}$, Wenjun YU Alistair G.L. BORTHWICK ${ }^{5}$, Yuanfang CHAI ${ }^{6}$, Zhaohua SUN ${ }^{2}$, Yitian $\mathbf{L I}^{2}$

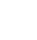

1 School of Hydraulic Engineering, Key Laboratory of Water-Sediment Sciences and Water Disaster Prevention of Hunan Province, Changsha University of Science \& Technology, Changsha 410114, China 2 State Key Laboratory of Water Resources and Hydropower Engineering Science, Wuhan
University, Wuhan 430072, China
3 Changjiang Institute of Survey, Planning, Design and Research, Wuhan 430010, China 4 Changjiang Waterway Institute of Planning, Design \& Research, Wuhan 430040, China 5 School of Engineering, The University of Edinburgh, The King's Buildings, Edinburgh EH9 3JL, UK 6 Department of Earth Sciences, Vrije Universiteit Amsterdam, Boelelaan 1085, $1081 \mathrm{HV}$ Amsterdam, The Netherlands E-mail: boyuan@csust.edu.cn 


\section{Abstract}

Channel evolution and depo-center migrations in braided reaches are significantly influenced by variations in runoff. This study examines the effect of runoff variations on the erosion-deposition patterns and depo-center movements within branching channels of the near-estuary reach of the Yangtze River. We assume that variations in annual mean duration days of runoff discharges, ebb partition ratios in branching channels, and the erosional/depositional rates of entire channels and sub-reaches are representative of variations in runoff intensity, flow dynamics in branching channels, and morphological features in the channels. Our results show that the north region of Fujiangsha Waterway, the Liuhaisha branch of Rugaosha Waterway, the west branch of Tongzhousha Waterway, and the west branch of Langshansha Waterway experience deposition or reduced erosion under low runoff intensity, and erosion or reduced deposition under high runoff intensity, with the depo-centers moving upstream and downstream, respectively. Other waterway branches undergo opposite trends in erosion-deposition patterns and depo-center movements as the runoff changes. These morphological changes may be associated with trends in ebb partition ratio as the runoff discharge rises and falls. By flattening the intra-annual distribution of runoff discharge, dam construction in the Yangtze Basin has altered the ebb partition ratios in waterway branches, affecting their erosion-deposition patterns and depo-center movements. Present trends are likely to continue into the future as a succession of large cascade dams is under construction along the upper Yangtze.

Keywords near-estuary reach, Yangtze River, runoff discharge, ebb partition ratio, 
erosion-deposition pattern, depo-center movement

\section{Introduction}

Morphological evolution of river systems is important to river management and regulation, and has become a growing issue over the past decades (Li et al., 2014; Zhu et al., 2017; Schletterer et al., 2019). Braided reaches are commonplace in rivers, with alternate development and shrinkage occurring between the main stem and secondary branches; such reaches often extend from the head source to the estuary (Jain and Sinha, 2004; Latrubesse, 2008; Jansen and Nanson, 2010; Chen et al., 2016; Li et al., 2016; Han et al., 2018; Zhu et al., 2017, 2019). It has been established that differences in evolutional processes between bifurcated branches are primarily caused by changes in lateral flow dynamics, driven by variations in flow discharge (i.e. upstream runoff discharge or downstream tidal discharge) (Chen et al., 2016; Han et al., 2018; Zhu et al., 2017, 2019), local human activities (e.g. channel improvement works, and sand excavation) (Kuang et al., 2014; Zheng et al., 2018; Dai and Ding, 2019), and Coriolisinduced circulation in estuarine areas (Wang et al., 2013; Li et al., 2011, 2014). Dams modulate runoff discharge in rivers worldwide and can drive the morphological evolution of braided reaches, as demonstrated by many inland rivers (Petts and Gurnell, 2005; Graf, 2006; Han et al., 2018; Alcayaga et al., 2019; Mendoza et al., 2019; Zhu et al., 2019) and estuarine areas (Warne et al., 2002; Sloff et al., 2013; Zhu et al., 2017; Liu et al., 2018; Zhou et al., 2018), noting that tidal discharges are relatively stable at the yearly time scale (Horrevoets et al., 2004; Jiang et al., 2012a; Zhu et al., 2017). For fluvial braided reaches, shrinking or developing trends of branching channels are often 
aggravated or interchanged after dam impoundment, caused by changes in unidirectional flow dynamics driven by the altered runoff discharge (Han et al., 2018; Zhu et al., 2019). However, the morphological evolution in branches of tidal-affected braided reaches (including bifurcated estuaries) are more intricate, mainly due to the complexity of bifurcating systems and the jacking effect of tidal currents (Zhang et al., 2015; Zhu et al., 2017, 2018). Marine dynamic factors, such as waves, longshore currents, and storm surges, further complicate morphological changes in estuarine areas (Kaliraj et al., 2014; Rangoonwala et al., 2016; Shen et al., 2019).

As the largest river on the Eurasian continent and the third longest in the world, the Yangtze has accommodated the construction of more than 50,000 dams since the 1950s (Yang et al., 2011, 2015). Moreover, the Yangtze River hosts 49 major braided reaches in its middle and lower region (including the Yangtze Estuary); these reaches are classified into three main types: straight braided reaches; slightly bending braided reaches; and goose-head braided reaches (Yu, 2013). Under the impact of the dams, the intra-annual distribution of runoff discharge has flattened, whereas the total yearly runoff flux has hardly changed (Zhao et al., 2018; Zhu et al., 2017, 2018, 2019). Consequently, changes to the natural evolutional trends of the branching channels have been generally identified in the braided reaches along the Yangtze River (Han et al., 2018; Zhu et al., 2017, 2019). Nevertheless, the braided near-estuary reach, which extends from the tidal current limit of the Yangtze River to the upper boundary-node of the Yangtze Estuary (Yu and Lu, 2005), has not yet been investigated comprehensively. Researchers have chiefly analyzed the evolutional courses of thalwegs, cross-sections, 
and flow hydrodynamics (e.g. net discharge ratios and flow velocities) in the branching channels of the near-estuary reach (Jiang et al., 2012b; Chen et al., 2012, 2016; Fan et al., 2017; Zhang and $\mathrm{Xu}$, 2017), but have not considered overall variations in channel morphology and systemic relationships between erosion-deposition patterns and variations in the flow hydrodynamics. This implies that, predictions of the future evolution of branching channels in this reach (Jiang et al., 2012b; Chen et al., 2016) might be unreliable. Moreover, the law of depo-center movement in the branching channels of the near-estuary reach has not been explored. (The depo-center is defined as the location where the sediment deposition rate is a maximum.) Depo-center movement has not been considered previously for other braided reaches or river systems as well, and deserves in-depth analysis given its indicative role regarding erosion-deposition distributions in the branching channels of a braided river.

In the present study, the overall morphological evolution and the law of depocenter migration in branching channels of the near-estuary reach of the Yangtze River are investigated, based on terrain and hydrodynamic data from 1950 to 2014. The findings may be transferable to other braided reaches worldwide, and should be useful in guiding future engineering projects that are planned for the near-estuary reach of the Yangtze River.

\section{Study area}

The near-estuary reach of the Yangtze River is located at the distal section of the Yangtze River (Fig. 1(a)), extending from Jiangyin (the tidal current limit) to Xuliujing (the upper boundary-node of the Yangtze Estuary) (Yu and Lu, 2005). The reach is of 
length $\sim 90 \mathrm{~km}$ (Fig. 1(b)). Its main braided waterways comprise the Fujiangsha, Rugaosha, Tongzhousha, and Langshansha Waterways (Fig. 1(b)). The middle branch of the Rugaosha Waterway connects with the north branch of the Fujiangsha Waterway, whilst the Liuhaisha branch of the Rugaosha Waterway connects to the middle and south branches of the Fujiangsha Waterway (Fig. 1(b)). Similarly, the east and west branches of the Langshansha Waterway connect with the corresponding branches of the Tongzhousha Waterway (Fig. 1(b)). This braided reach is influenced by tides, with multi-year (1950-2014) average tidal ranges of 1.68 and $2.04 \mathrm{~m}$ at Jiangyin and Xuliujing (Fig. 1(b)) (Zhu et al., 2018). Due to the relative stability of tidal forcing at the yearly time scale (Horrevoets et al., 2004; Jiang et al., 2012a; Zhu et al., 2017), the mean annual tidal level at Xuliujing (the lower boundary of this reach, Fig. 1(b)) is almost constant (Zhu et al., 2018). By comparison, runoff discharge from Datong hydrological station (Fig. 1(a)), representing the most downstream reach (Zhao et al., 2018; Zhu et al., 2017, 2018, 2019), experiences significant intra-annual variability, exhibited by a reduced flood discharge occurrence frequency and increased middle-low discharge occurrence frequency (Zhu et al., 2017, 2018, 2019). However, the annual runoff discharge is almost constant (Zhao et al, 2018; Zhu et al., 2017, 2018, 2019), with a multi-year (1950-2014) average value of $8930 \mathrm{~m}^{3} / \mathrm{s}$ (CWRC, 2016). To achieve the national goal of a Golden Waterway, extensive channel improvements have been implemented along the near-estuary reach, including an upstream extension of the Deepwater Channel Project (Chen et al., 2012; Wu et al., 2013; Yang and Lin, 2013; Ni et al., 2014; Xu et al., 2014). 

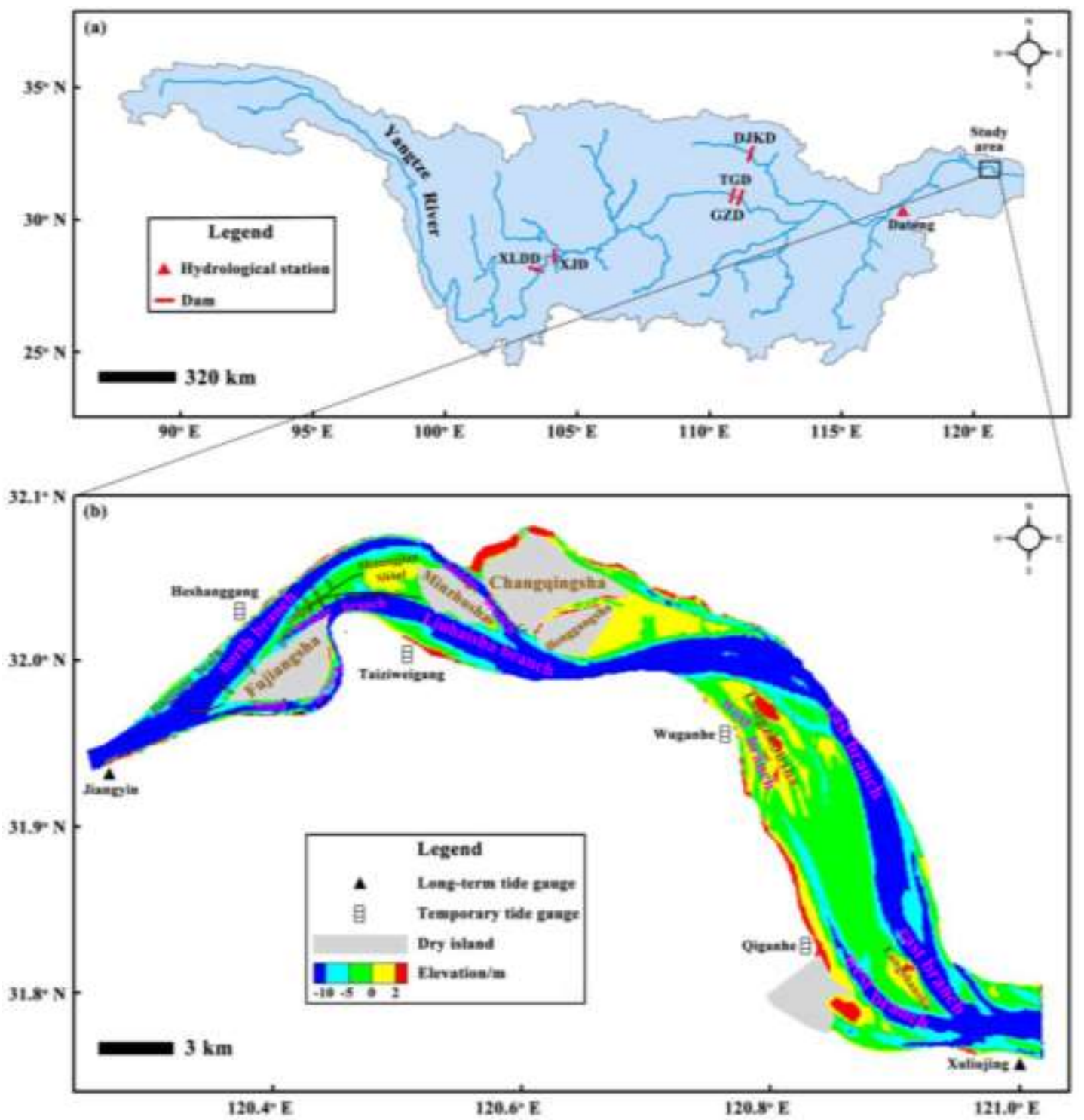

Fig. 1 The Yangtze Basin and its near-estuary reach. (a) Outline map of the Yangtze Basin indicating the locations of the Xiluodu Dam (XLDD), Xiangjia Dam (XJD), Three Gorges Dam (TGD), Gezhou Dam (GZD), Danjiangkou Dam (DJKD), Datong hydrological station, and the near-estuary reach (the study area). The years of impoundment of the dams were 2013, 2012, 2003, 1981 and 1968, respectively. (b) Bathymetry of the branched near-estuary reach, with positions of tide gauges superimposed.

\section{Materials and methods}

\subsection{Data information}

Observed daily runoff discharge time series at Datong station from 1950 to 2014, and hourly ebb tidal discharges in the branching channels and hourly ebb tidal levels at temporary tide gauges in the vicinity of the waterways from $30^{\text {th }}$ August to $10^{\text {th }}$ 
144 September 2004 and from $17^{\text {th }}$ January to $12^{\text {th }}$ February 2005 were obtained from the 145 Changjiang Water Resources Commission (China). Bed-elevation point data digitized 146 from surveyed navigational charts in 2005 and 2007 were provided by the Shanghai 147 Estuarine \& Coastal Science Research Center (China); those in 2011 and 2014 were 148 obtained from the Changjiang Waterway Bureau (China). Channel volumes below $-5 \mathrm{~m}$ 149 and $-10 \mathrm{~m}$ isobaths in the two branches of the Tongzhousha Waterway were acquired 150 from the Changjiang Waterway Bureau (China). The following data on hydrodynamics 151 and morphology were gathered from the open literature: (1) yearly wet-season average 152 ebb partition ratios for branching channels in 1977, 1983, 1993, 1998, 2006, and 2011; 153 (2) minimum widths of $-8 \mathrm{~m}$ and $-10 \mathrm{~m}$ isobaths in the north branch of the Fujiangsha 154 Waterway from 2005 to 2012; (3) cross-sectional profiles at the entrance of the south 155 branch of the Fujiangsha Waterway in 1977, 1983, 1993, 1998, 2006, and 2011; and (4) 156 cross-sectional areas of the two branches of the Rugaosha Waterway under bankfull 157 discharge in 1977, 1983, 1993, 1998, 2006, and 2011. Table 1 summarizes the data 158 sources.

159 Table 1 Data information

\begin{tabular}{cccc}
\hline Type & Name & Time & Source(s) \\
\hline \multirow{3}{*}{ Hydrodynamics } & $\begin{array}{c}\text { Daily runoff discharge } \\
\text { series }\end{array}$ & $1950-2014$ & $\begin{array}{c}\text { Changjiang Water } \\
\text { Resources } \\
\text { Commission (China) }\end{array}$ \\
\cline { 2 - 4 } & $\begin{array}{c}\text { Hourly ebb tidal } \\
\text { discharge series in the } \\
\text { branching channels }\end{array}$ & $\begin{array}{c}\text { 2004.08.30-2004.09.10, } \\
\text { 2005.01.17-2005.02.12 }\end{array}$ & $\begin{array}{c}\text { Changiang Water } \\
\text { Resources } \\
\text { Commission (China) }\end{array}$ \\
\cline { 2 - 4 } & $\begin{array}{c}\text { Hourly tidal level series } \\
\text { at temporary tide gauges } \\
\text { in vicinity of the } \\
\text { waterways a) }\end{array}$ & $2004.08 .30-2004.09 .10$, & $\begin{array}{c}\text { Changjiang Water } \\
\text { Resources }\end{array}$ \\
& Yearly wet-season & $1977,1983,1993,1998$, & Chen et al., 2016 \\
\cline { 2 - 4 } & Yemmission (China)
\end{tabular}




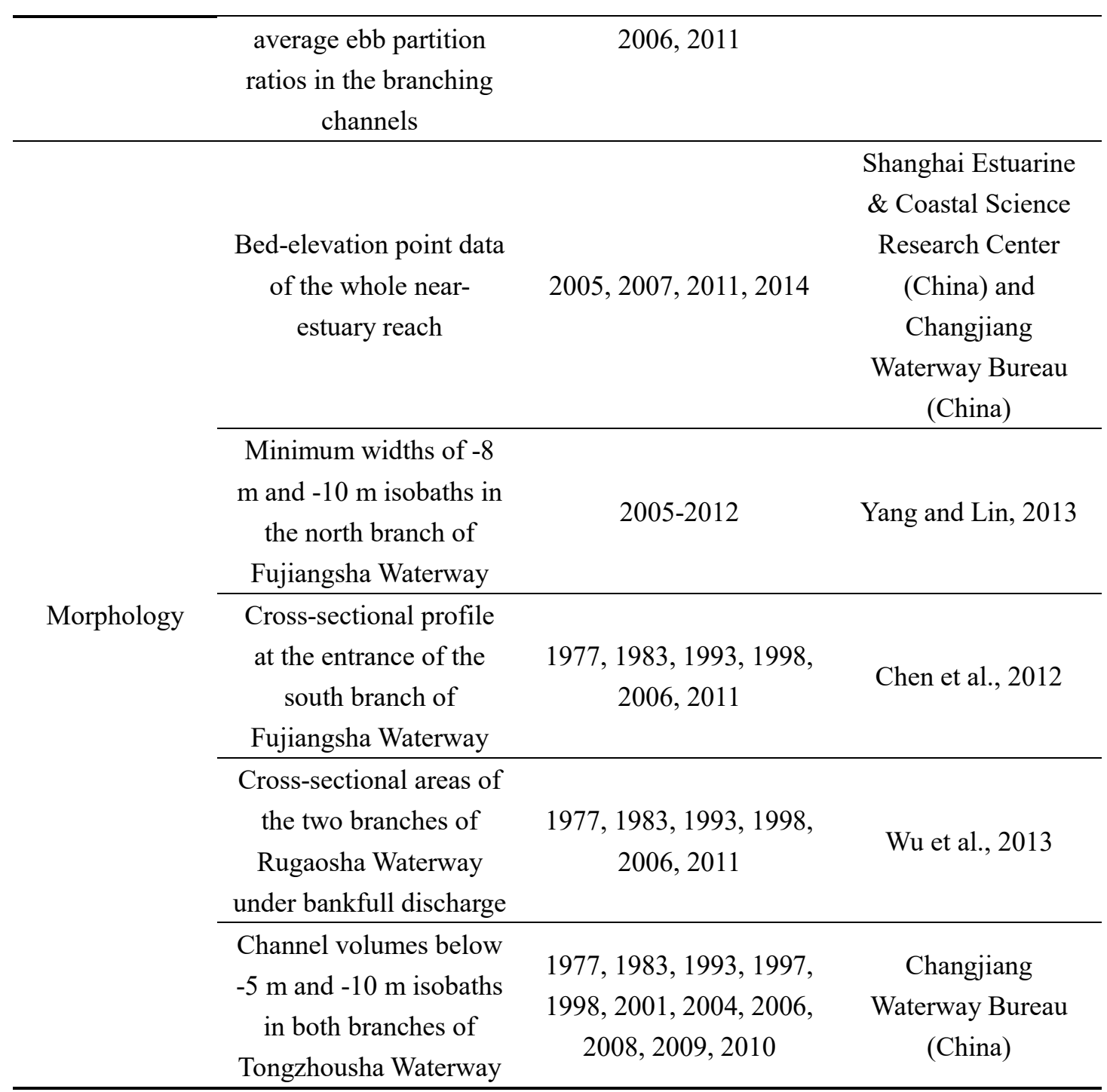

a) The nearby temporary tide gauges are at Heshanggang, Taiziweigang, Wuganhe, and Qiganhe stations, as indicated on Fig. 1(b).

\subsection{Processing of bed-elevation point data}

Bed-elevation point data from 2005, 2007, 2011, and 2014 were projected onto Beijing 54 coordinates using ArcGIS 10.2 during digitization, with reference to 1985 national elevation benchmarks. Bed elevations and point locations had previously been determined from measurements using dual-frequency echo sounders and GPS positioning. The measurement errors for bed-elevation of $\pm 0.1 \mathrm{~m}$ and location of $\pm 1 \mathrm{~m}$ were taken to be acceptable, noting the huge scale of bed-elevation changes that can occur annually (Luan et al., 2016). The proportional scales for all the four sets of terrain 
data are 1:10,000, with sample density of $10-122 \mathrm{pts} / \mathrm{km}^{2}$ (i.e. spacing of $50-500 \mathrm{~m}$ between two neighboring points), and so a grid resolution of $25 \mathrm{~m} \times 250 \mathrm{~m}$ was adopted when calculating morphological changes using Kriging interpolation.

\subsection{Interpretation of depo-centers}

A depo-center in a branching channel is defined as the location where the maximum depositional rate of sediment occurs. Upstream and downstream depo-center movements in branching channels are identified by interpreting changes in river-bed elevation caused by erosion and deposition in upper and lower sub-reaches of roughly the same length. Increases in depositional rate or decreases in erosional rate of the upper or lower sub-reaches indicate that the depo-centers in the corresponding channels are moving towards the sub-reaches, whereas decreases in depositional rate or increases in erosional rate of the sub-reaches indicate depo-center movements away from the subreaches. Fig. 2 illustrates the divisions of upper and lower sub-reaches in the branching channels of the four main braided waterways.

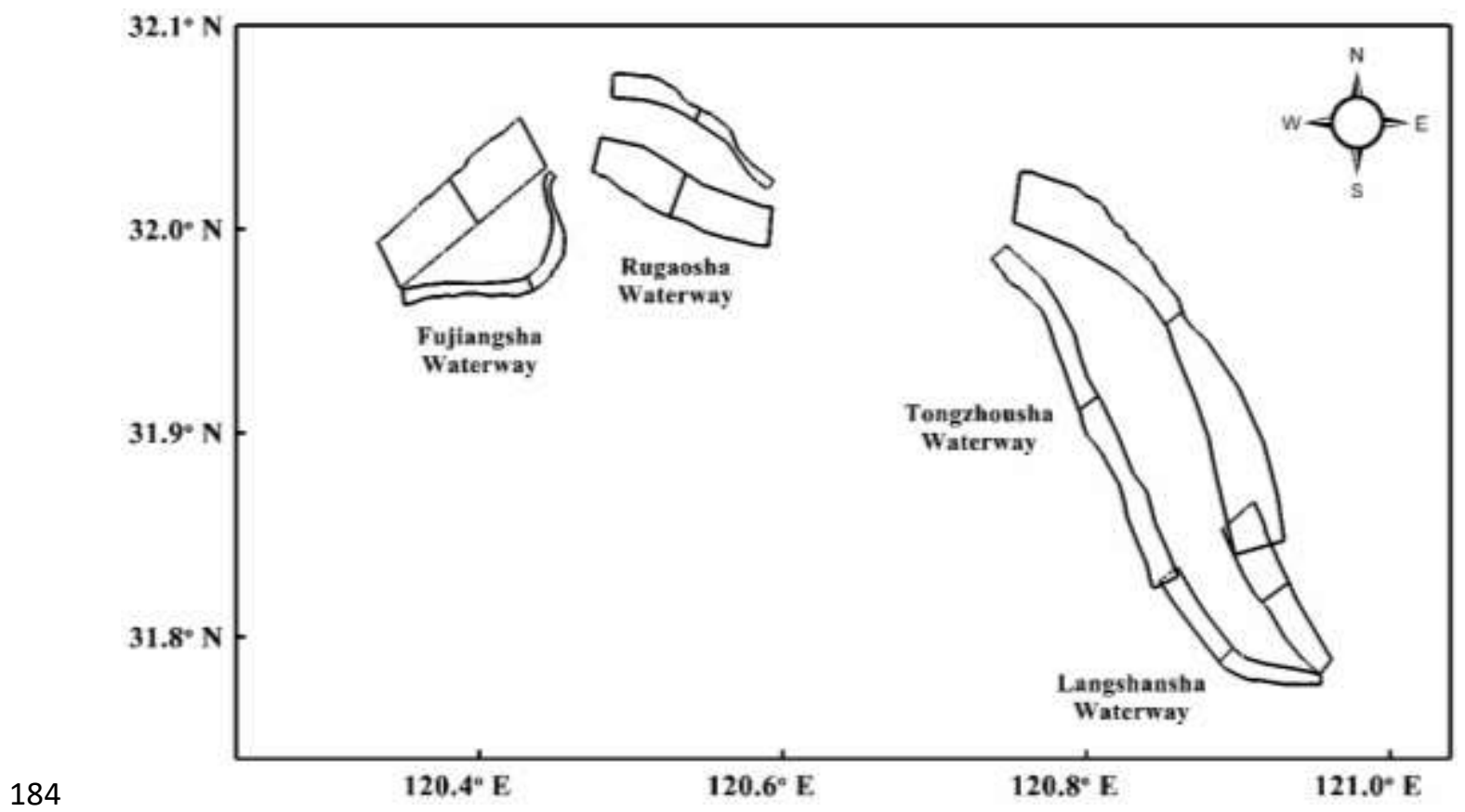


Fig. 2 Boundaries of branching channels and their upper and lower sub-reaches.

4 Results

4.1 Hydrodynamic variations

188

\subsubsection{Runoff discharge}

189

Fig. 3 shows that the yearly runoff discharge changed little, whereas the intraannual distribution of runoff discharge flattened significantly, from the pre-TGD period (in which the GZD and the DJKD impounded water, Fig. 1) before the TGD became operational to the post-TGD period (in which the TGD, the XJD and the XLDD impounded water, Fig. 1) afterwards. It can be seen that the multi-year average duration days of discharges $<10,000 \mathrm{~m}^{3} / \mathrm{s}$ and $>50,000 \mathrm{~m}^{3} / \mathrm{s}$ decreased significantly, while those of $10,000-20,000 \mathrm{~m}^{3} / \mathrm{s}$ increased substantially.

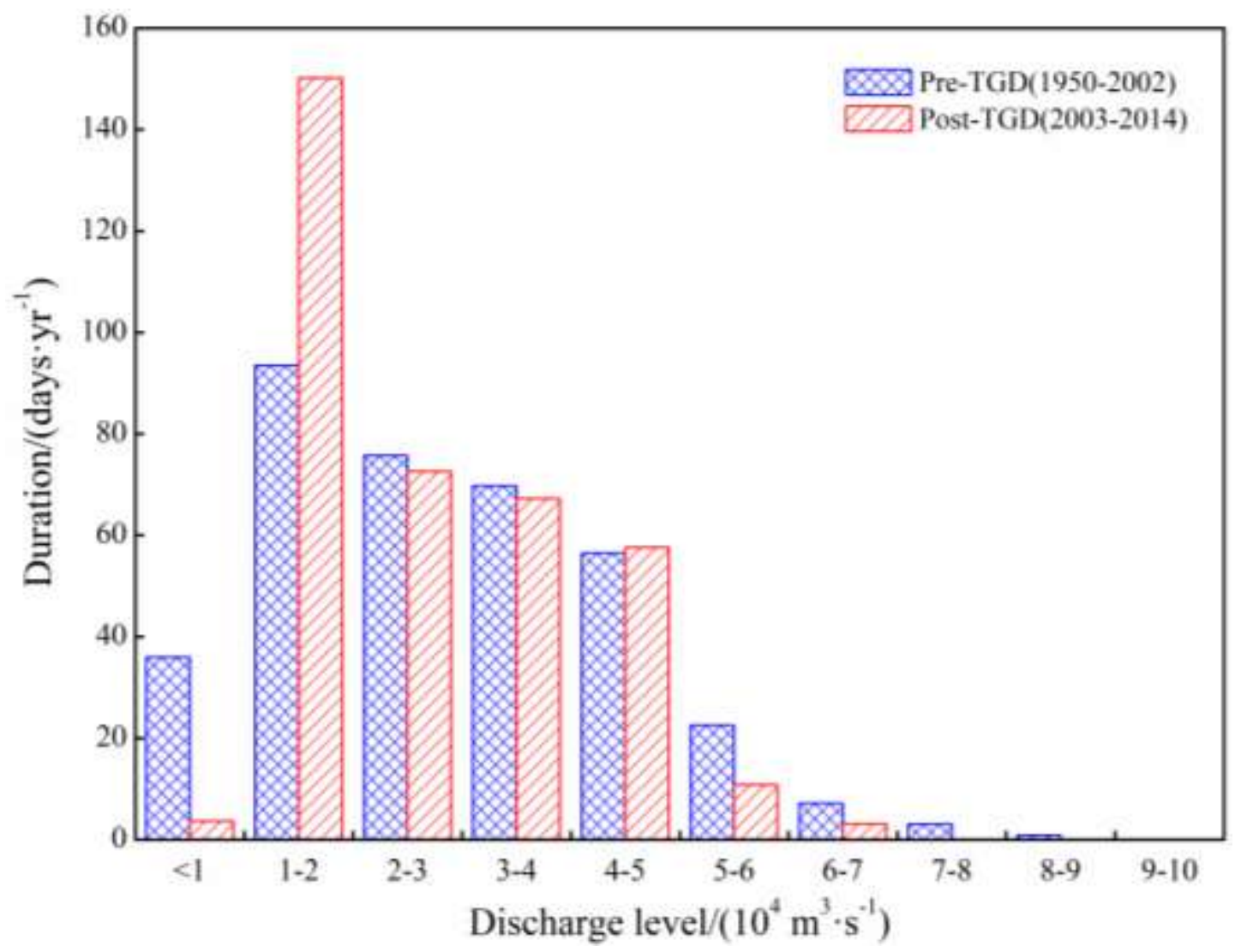

Fig. 3 Histogram of annual mean duration days for different runoff discharge levels at Datong station 198 from 1950 to 2002 before impoundment of the TGD (and also XJD and XLDD, Fig. 1(a)) and from 
2003 to 2014 after its impoundment, during which time both XLDD and XJD also commenced operation.

\subsubsection{Ebb partition ratio}

\subsubsection{Yearly trends}

Fig. 4 shows that the yearly wet-season average ebb partition ratios in the north region (including the north branch, middle branch, and Shuangjian shoal, Fig. 1(b)) of Fujiangsha Waterway, the Liuhaisha branch of Rugaosha Waterway, the west branch of Tongzhousha Waterway, and the west branch of Langshansha Waterway exhibited decreasing trends from 1977 to 2011, whereas the ebb partition ratios for the other branches of the four waterways presented increasing trends.
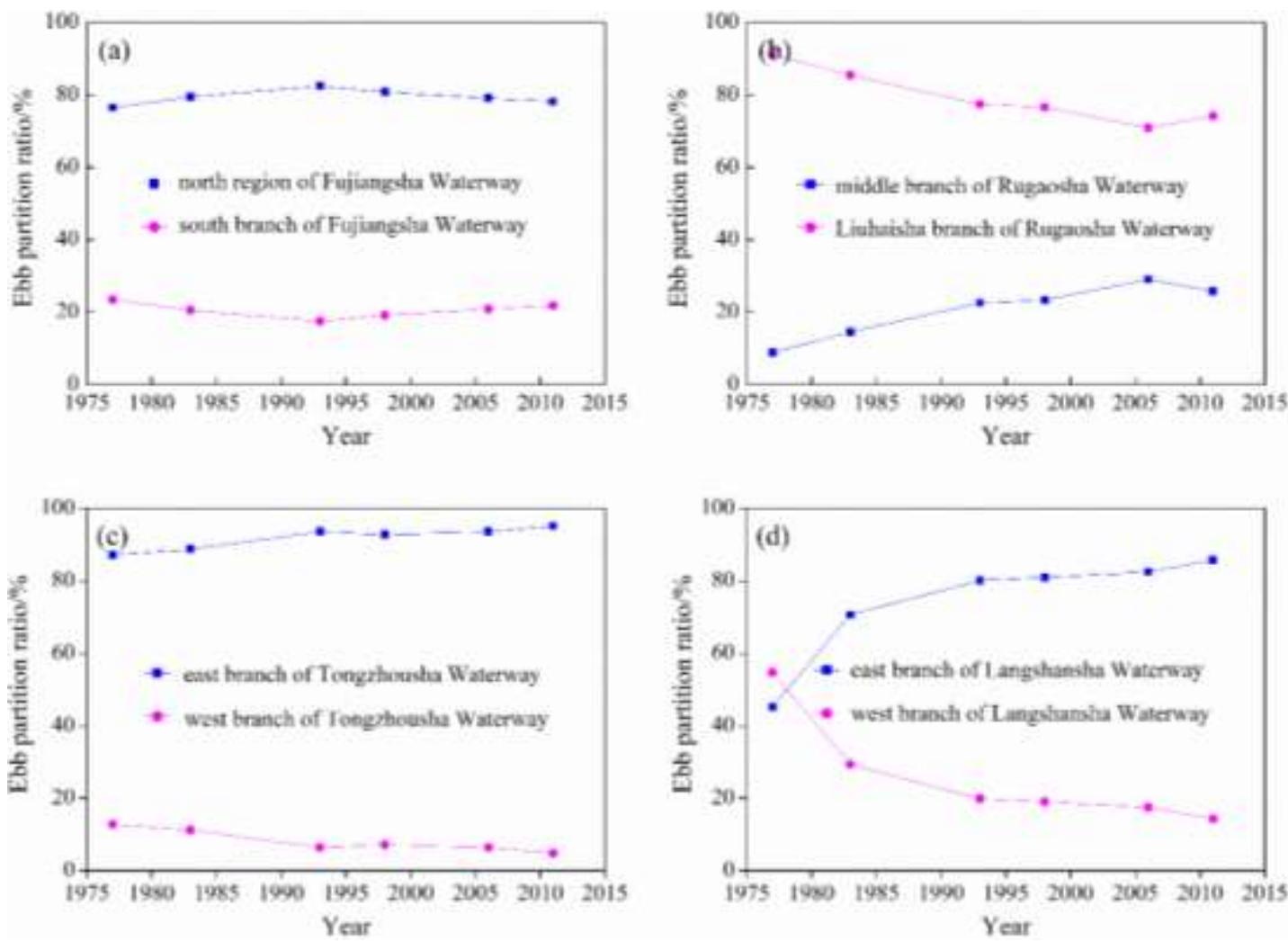

Fig. 4 Trends in annual wet-season average ebb partition ratios for branching channels of the following waterways: (a) Fujiangsha; (b) Rugaosha; (c) Tongzhousha; and (d) Langshansha.

\subsubsection{Changes under different runoff conditions}

Fig. 5 presents the variations in ebb partition ratio with tidal range obtained for the 
$21512^{\text {th }}$ February 2005 , for runoff discharges of $36,000 \mathrm{~m}^{3} / \mathrm{s}$ and $11,000 \mathrm{~m}^{3} / \mathrm{s}$. The tidal data

216 were obtained using temporary tide gauges (see Fig. 1(b) for locations). For all tidal

217 range values considered, the ebb partition ratio at a runoff discharge of $36,000 \mathrm{~m}^{3} / \mathrm{s}$ was

218 invariably larger than that at $11,000 \mathrm{~m}^{3} / \mathrm{s}$ in the north region of Fujiangsha Waterway,

219 the Liuhaisha branch of Rugaosha Waterway, the west branch of Tongzhousha

220 Waterway, and the west branch of Langshansha Waterway. This implies that the higher

221 runoff discharge caused flow to divert into these branches, with the opposite occurring

222 in the other waterway branches.
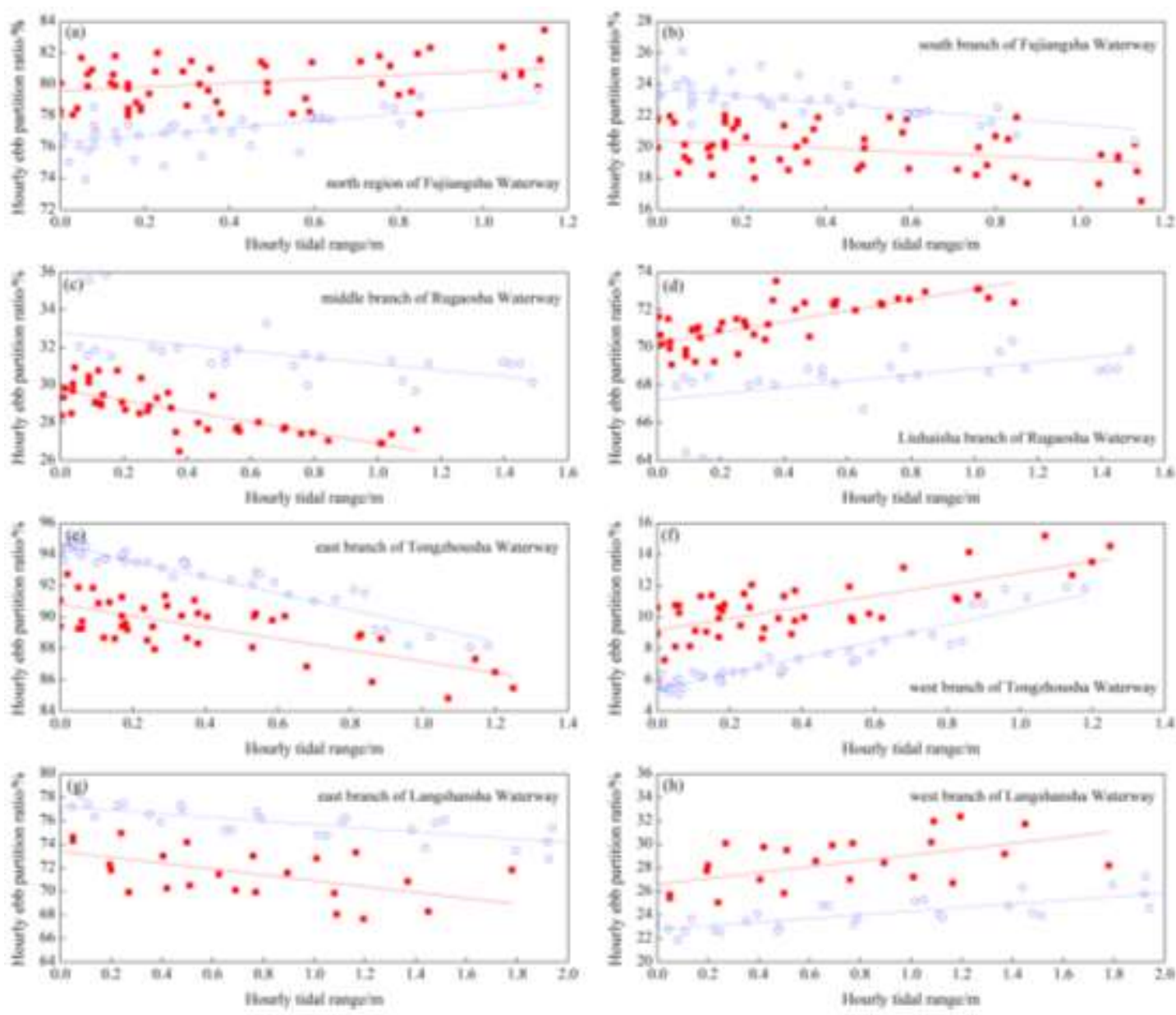

- $36,000 \mathrm{~m}^{\mathrm{l}} \mathrm{s}^{\mathrm{t}}$

$11.500 \mathrm{~m}^{2} \mathrm{x}^{2}$

Trend lise for 11,000 m's'

Fig. 5 Relationships between ebb partition ratio and tidal range for two runoff discharge levels in 
the branching channels of the waterways: (a) north region of Fujiangsha Waterway; (b) south branch of Fujiangsha Waterway; (c) middle branch of Rugaosha Waterway; (d) Liuhaisha branch of Rugaosha Waterway; (e) east branch of Tongzhousha Waterway; (f) west branch of Tongzhousha Waterway; (g) east branch of Langshansha Waterway; and (h) west branch of Langshansha Waterway. Each hourly tidal range value was determined by subtracting the average of preceding and succeeding low tidal levels from the hourly tidal level.

4.2 Morphological variations

\subsubsection{Whole channel}

\subsubsection{Yearly trends}

Both the annual time series of minimum widths of the $-8 \mathrm{~m}$ and $-10 \mathrm{~m}$ isobaths in the north branch of the Fujiangsha Waterway present decreasing temporal trends (Fig. 6(a)), indicating that the north branch has been progressively shrinking. Given that the north branch is the main channel at the north of Fujiangsha Island (Fig. 1(b)), this shrinkage implies that the northern region (including the north branch, middle branch, and Shuangjian shoal) of the Fujiangsha Waterway has been experiencing morphological decline. By contrast, the deep channel of the cross-section at the entrance of the south branch of Fujiangsha Waterway underwent significant erosion from 1977 to 2011 (Fig. 6(b)), suggesting the morphology of the south branch was undergoing rapid development. The cross-sectional areas of the middle branch and the Liuhaisha branch of Rugaosha Waterway presented increasing and decreasing trends under bankfull discharge (Figs. 6(c-d)), implying the middle branch and Liuhaisha branch were experiencing developing and declining morphological trends respectively.

Figs. 6(e-f) show that the channel volume below the $-10 \mathrm{~m}$ isobath in the east branch of the Tongzhousha Waterway has been presenting an increasing trend, whereas that below the $-5 \mathrm{~m}$ and $-10 \mathrm{~m}$ isobaths in the west branch of the Tongzhousha Waterway has a 
respectively. and declining trends.
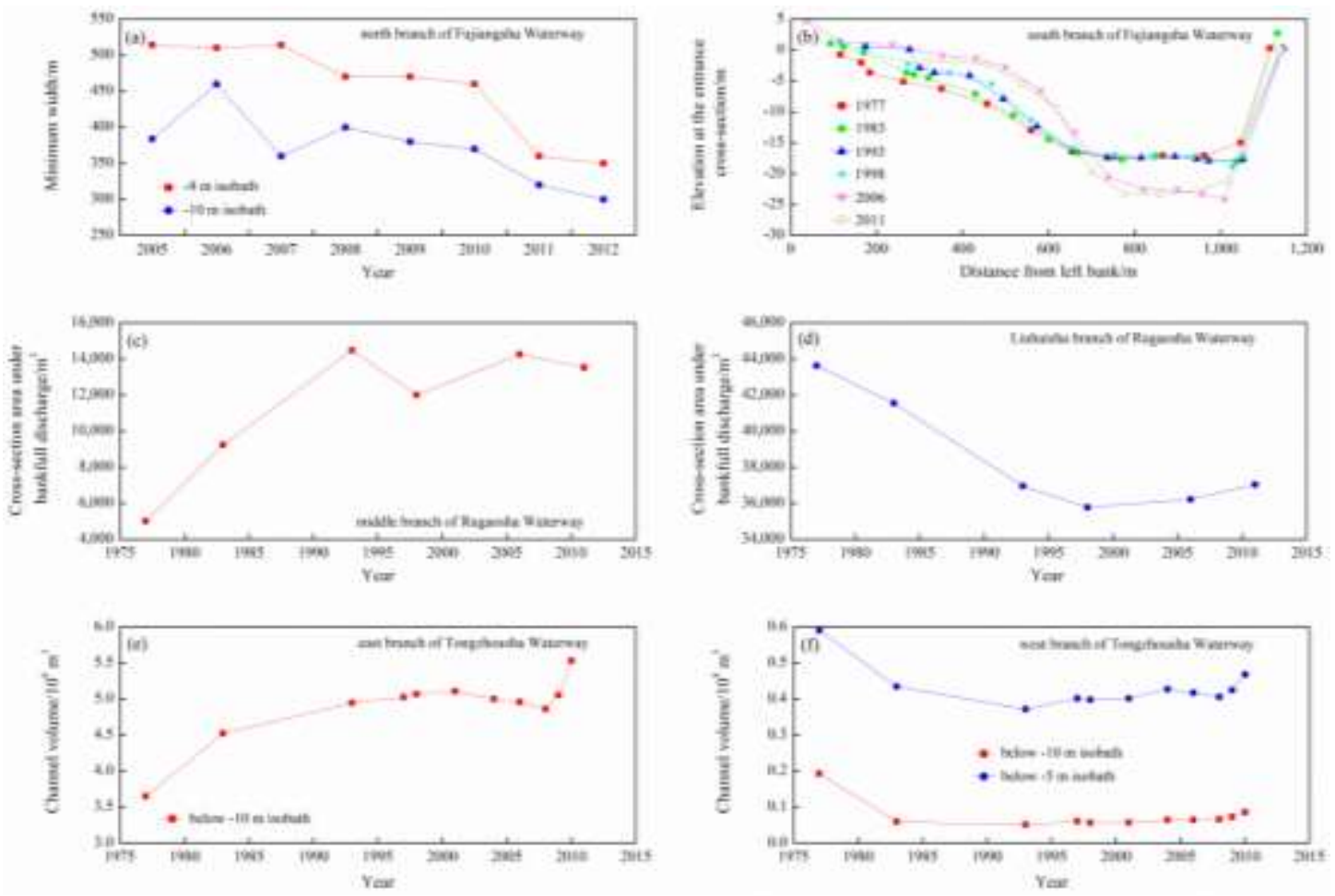

Fig. 6 Evolution of the branching channels of the waterways: (a) annual values of minimum widths of $-8 \mathrm{~m}$ and $-10 \mathrm{~m}$ isobaths in the north branch of Fujiangsha Waterway; (b) evolution of the crosssection at the entrance of the south branch of Fujiangsha Waterway; (c) annual time series of the cross-sectional area under bankfull discharge of the middle branch of Rugaosha Waterway; (d) evolution of the cross-sectional area under bankfull discharge of Liuhaisha branch of Rugaosha Waterway; (e) temporal behavior of channel volume below $-10 \mathrm{~m}$ isobath of the east branch of Tongzhousha Waterway; and (f) temporal behavior of channel volume below $-10 \mathrm{~m}$ and $-5 \mathrm{~m}$ isobaths of the west branch of Tongzhousha Waterway.

\subsubsection{Changes under different runoff conditions}

Table 2 lists erosion-deposition rates in the branching channels and the corresponding duration days of relevant runoff discharges during 2005-2007, 20072011, and 2011-2014. Fig. 7 displays plan distributions of erosion-deposition rates for 
the whole near-estuary reach in $2005,2007,2011$, and 2014. Of these periods, 20052007 was the driest, being associated with the least duration days of flood discharges ( $>$ $50,000 \mathrm{~m}^{3} / \mathrm{s}$ and $>60,000 \mathrm{~m}^{3} / \mathrm{s}$ ) and the most duration days of low and middle-low discharges $\left(<10,000 \mathrm{~m}^{3} / \mathrm{s}\right.$ and $\left.10,000-20,000 \mathrm{~m}^{3} / \mathrm{s}\right)$ (Table 2). This is because the 2005-2007 period contained an extreme dry year event that affected the Yangtze Basin in 2006 (Zhu et al., 2018); during this event no discharge exceeded 40,000 $\mathrm{m}^{3} / \mathrm{s}$, and the duration days of low and middle-low discharges were at 7 days and 185 days. The 2007-2011 period was wettest, with the largest number of duration days for flood discharges (especially $>60,000 \mathrm{~m}^{3} / \mathrm{s}$ ) and lower numbers of duration days for low and middle-low discharges than in 2005-2007 (Table 2). The 2007-2011 period included the flood year of 2010 (Zhu et al., 2018), the only year during which the discharge exceeded $60,000 \mathrm{~m}^{3} / \mathrm{s}$ in the total period from 2005 to 2014 . In 2010 , the duration of the $>60,000$ $\mathrm{m}^{3} / \mathrm{s}$ discharge lasted 36 days. The runoff intensity in 2011-2014 was between that in the foregoing two periods (Table 2).

The entire northern region of Fijiangsha Waterway (including the north branch, middle branch, and Shuangjian shoal) experienced deposition during 2005-2007, severe erosion during 2007-2011, and slight erosion during 2011-2014 (Table 2), indicating that low and high values of runoff intensity promoted deposition and erosion respectively. This erosion-deposition behavior in the north region is also confirmed by changes in the deep channel area (see Fig. 7), which shrank in the period from 2005 to 2007 (Figs. 7(a-b)) before experiencing significant growth from 2007 to 2011 (Figs. 7(b-c)) and from 2011 to 2014 (Figs. 7(c-d)). Erosion occurred in the south branch 
during all three periods, with a much larger erosional rate during 2005-2007 than 20112014 (Table 2). Even though severe erosion occurred in the south branch during 20072011 when the largest number of flood discharge duration days were experienced, the rate of erosion was smaller than in the north region (Table 2; Figs. 7(b-c)). This implies that the north region and south branch underwent roughly the reverse erosiondeposition behavior under runoff changes.

In accordance with changes in runoff intensity, the Liuhaisha branch of Rugaosha Waterway experienced deposition during 2005-2007, significant erosion during 20072011, and less significant erosion during 2011-2014 (Table 2). This erosion-deposition behavior was linked to changes in the deep channel area (Fig. 7) which witnessed obvious shrinkage from 2005 to 2007 (Figs. 7(a-b)) and significant growth from 2007 to 2011 (Figs. 7(b-c)) and 2011 to 2014 (Figs. 7(c-d)). The middle branch of Rugaosha Waterway exhibited a similar erosion-deposition pattern to that of the Liuhaisha branch (Table 2), influenced by the flood-tide-driven sediment supply from the lower two braided waterways during the dry period of 2005-2007 (Zhu et al., 2018) and engineering projects implemented in the vicinity (Fig. 1(b); Chen et al., 2012; Wu et al., 2013).

The two branches of Tongzhousha Waterway did not exhibit opposite erosiondeposition patterns under runoff change (Table 2); this was perhaps because the gradual decline of the west branch in recent years (Ni et al., 2014) caused the Tongzhousha Waterway effectively to become a single river channel dominated by the east branch. In this case, the discharge, regardless of runoff intensity, passed mainly through the east 
branch, leading to erosion or deposition depending on the flow speed within the branch (Table 2). Meanwhile, regulation projects implemented along the Tongzhousha Waterway also impacted on the erosion-deposition pattern (Ni et al., 2014). Even so, the low runoff intensity during 2005-2007 promoted shrinkage of the west branch and shortened the deep channel of the west branch (Figs. 7(a-b)), whereas the high runoff intensities during 2007-2011 and 2011-2014 facilitated development of the west branch, lengthening its deep channel (Figs. 7(b-c) and 7(c-d)). The upper and lower deep channels became connected within the west branch from 2011 to 2014 (Figs. 7(c-d)).

Depositional rates in the east branch of Langshansha Waterway were smallest during 2005-2007 and largest during 2007-2011 (Table 2), indicating that low and high runoff intensities respectively facilitated the development and decline of the east branch. As shown in Fig. 7, the deep channel area in the east branch experienced obvious growth from 2005 to 2007, and altered from a bifurcating to a single channel pattern as its width increased (Figs. 7(a-b)). However, from 2007 to 2011 and 2011 to 2014 the deep channel area re-established a bifurcated pattern, with decreased width (Figs. 7(bc) and $7(\mathrm{c}-\mathrm{d}))$. The west branch underwent an almost opposite erosion-deposition pattern, with deposition during 2005-2007 and 2011-2014, and erosion during 20072011 (Table 2); this implied that low runoff intensity promoted shrinkage of the west branch whereas high runoff intensity promoted growth. Meanwhile, the deep channel of the west branch shortened during 2005-2007 (Figs. 7(a-b)) and lengthened during 2007-2011 (Figs. 7(b-c)) and 2011-2014 (Figs. 7(c-d)).

In summary, low runoff intensity generally promoted development of the south 
334 branch of Fujiangsha Waterway, the middle branch of Rugaosha Waterway, the east 335 branch of Tongzhousha Waterway, and the east branch of Langshansha Waterway, while 336 usually facilitating morphodynamic decline of the other branches of the braided 337 waterways. High runoff intensity produced essentially the opposite effect. 
Table 2 Erosional/depositional rates (deposition positive-valued, and erosion negative-valued) of branching channels at the near-estuary reach of the Yangtze River over different periods, and corresponding multi-year average duration days of different runoff discharges at Datong station

\begin{tabular}{|c|c|c|c|c|c|c|c|}
\hline \multirow[t]{2}{*}{ Waterway } & \multirow{2}{*}{$\begin{array}{l}\text { Branching } \\
\text { channel }\end{array}$} & \multirow[t]{2}{*}{ Period } & \multirow{2}{*}{$\begin{array}{l}\text { Erosional/Depositional } \\
\quad \text { rate } /\left(\mathrm{m} \cdot \mathrm{yr}^{-1}\right)^{\text {a) }}\end{array}$} & \multicolumn{4}{|c|}{$\begin{array}{l}\left.\text { Annual mean duration days of runoff discharge at Datong station/(days } \cdot \mathrm{yr}^{-1}\right) \\
\text { b) }\end{array}$} \\
\hline & & & & $<10,000 \mathrm{~m}^{3} \cdot \mathrm{s}^{-1}$ & $10,000-20,000 \mathrm{~m}^{3} \cdot \mathrm{s}^{-1}$ & $>50,000 \mathrm{~m}^{3} \cdot \mathrm{s}^{-1}$ & $>60,000 \mathrm{~m}^{3} \cdot \mathrm{s}^{-1}$ \\
\hline \multirow{6}{*}{ Fujiangsha } & \multirow{3}{*}{ north region } & $\begin{array}{l}2005- \\
2007\end{array}$ & 0.650 & 4 & 170 & 10 & 0 \\
\hline & & $\begin{array}{l}2007- \\
2011\end{array}$ & -0.458 & 0 & 168 & 14 & 7 \\
\hline & & $\begin{array}{l}2011- \\
2014\end{array}$ & -0.186 & 0 & 156 & 14 & 0 \\
\hline & \multirow{3}{*}{ south branch } & $\begin{array}{l}2005- \\
2007\end{array}$ & -0.147 & 4 & 170 & 10 & 0 \\
\hline & & $\begin{array}{l}2007- \\
2011\end{array}$ & -0.314 & 0 & 168 & 14 & 7 \\
\hline & & $\begin{array}{l}2011- \\
2014\end{array}$ & -0.020 & 0 & 156 & 14 & 0 \\
\hline \multirow{6}{*}{ Rugaosha } & \multirow{3}{*}{ middle branch } & $\begin{array}{l}2005- \\
2007\end{array}$ & 0.348 & 4 & 170 & 10 & 0 \\
\hline & & $\begin{array}{l}2007- \\
2011\end{array}$ & -0.603 & 0 & 168 & 14 & 7 \\
\hline & & $\begin{array}{l}2011- \\
2014\end{array}$ & -0.123 & 0 & 156 & 14 & 0 \\
\hline & \multirow{3}{*}{ Liuhaisha branch } & $\begin{array}{l}2005- \\
2007\end{array}$ & 0.902 & 4 & 170 & 10 & 0 \\
\hline & & $\begin{array}{l}2007- \\
2011\end{array}$ & -0.224 & 0 & 168 & 14 & 7 \\
\hline & & $\begin{array}{l}2011- \\
2014 \\
\end{array}$ & -0.156 & 0 & 156 & 14 & 0 \\
\hline Tongzhousha & east branch & $\begin{array}{l}2005- \\
2007\end{array}$ & 0.310 & 4 & 170 & 10 & 0 \\
\hline
\end{tabular}




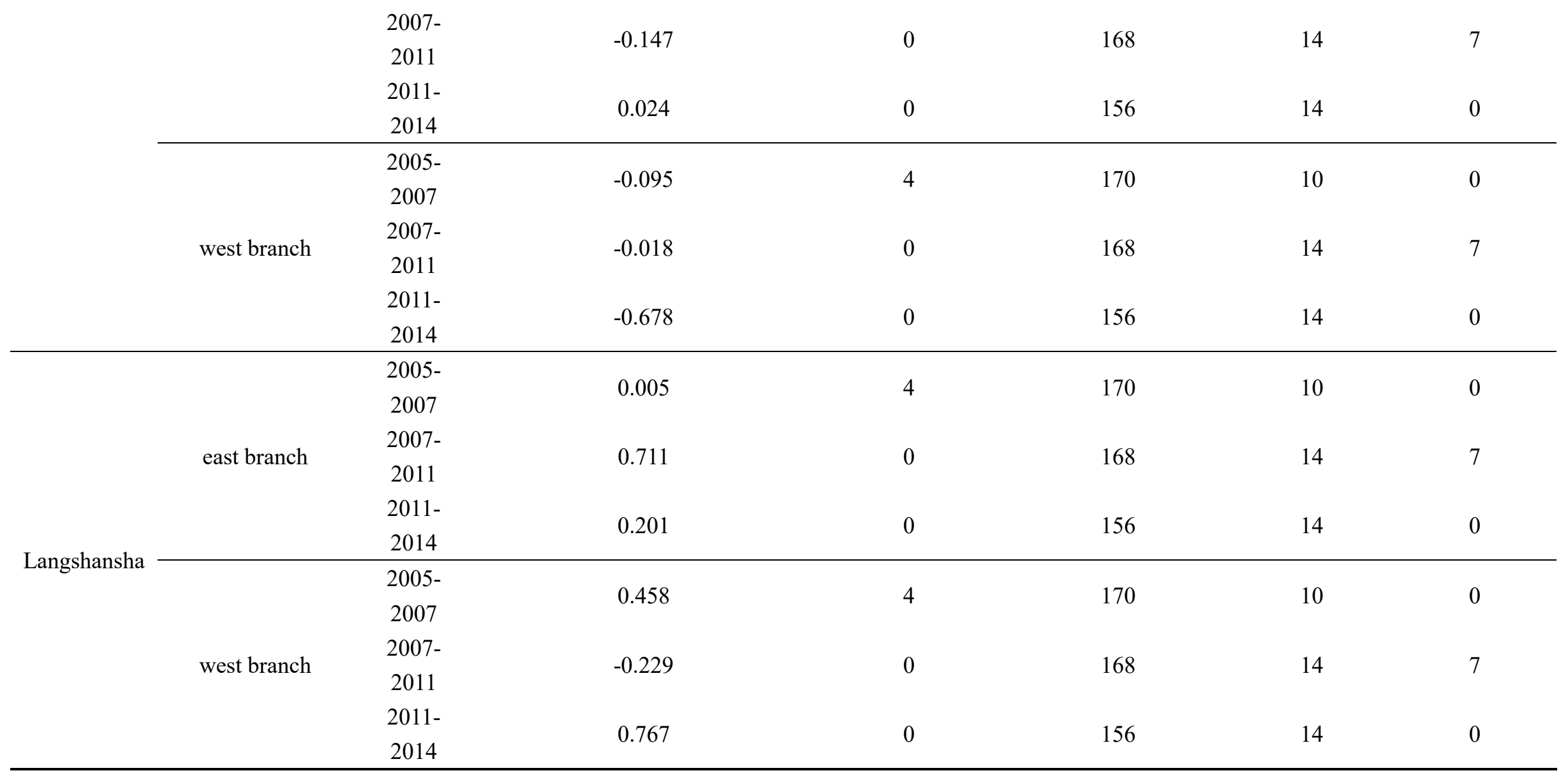

340 a) Fig. 2 shows boundaries of the branching channels.

341 b) $<10,000 \mathrm{~m}^{3} / \mathrm{s}, 10,000-20,000 \mathrm{~m}^{3} / \mathrm{s}$ and $>50,000 \mathrm{~m}^{3} / \mathrm{s}$ are the discharge levels experiencing obvious changes in duration days over different periods (Fig. 3), whereas $34260,000 \mathrm{~m}^{3} / \mathrm{s}$ approximates the bed-forming discharge in the near-estuary reach of the Yangtze River (Yun, 2004). 


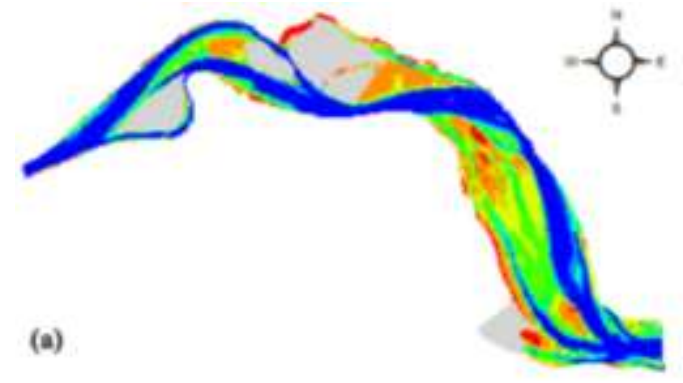

(a)

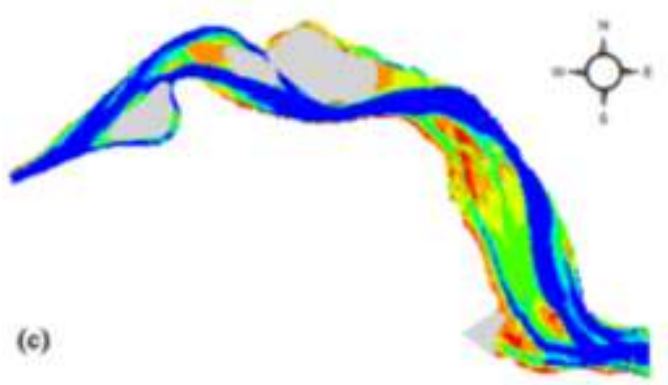

Blevation/m

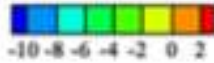
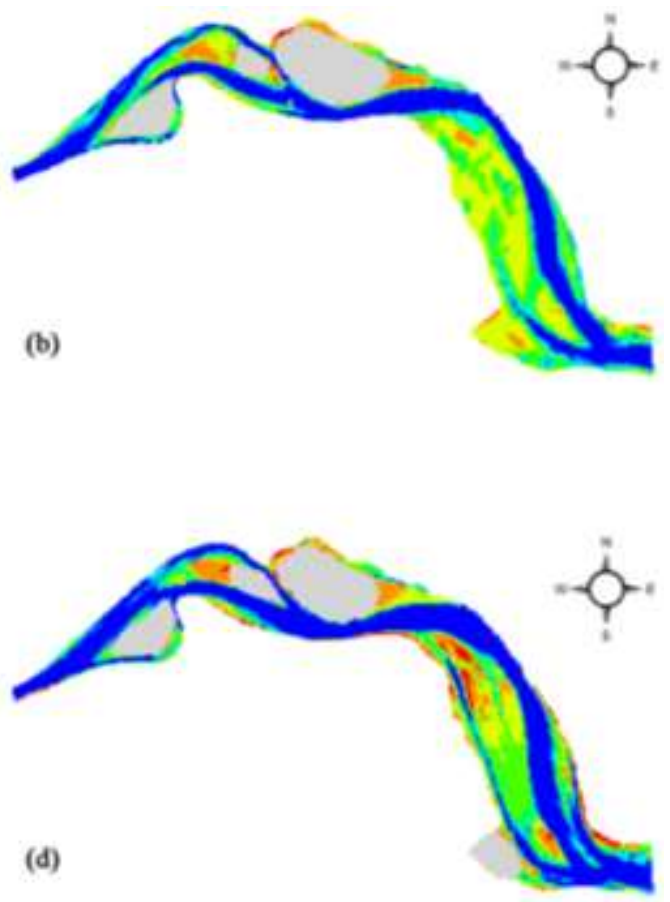

Dry island

Fig.7 Plan distributions of river bed elevation at the near-estuary reach of the Yangtze River in (a) 2005, (b) 2007, (c) 2011, and (d) 2014.

\subsubsection{Depo-center movement}

The data listed in Table 3 indicate that depo-centers in the north region of Fujiangsha Waterway, the Liuhaisha branch of Rugaosha Waterway, the west branch of Tongzhousha Waterway, and the west branch of Langshansha Waterway moved upstream when the runoff intensity declined, and moved downstream when runoff intensity rose. The situation for the other branches of the waterways was quite the opposite. The details are as follows:

In the north region of the Fujiangsha Waterway, the depositional rate in the upper sub-reach was larger than in the lower sub-reach during 2005-2007 (with low runoff intensity) (Table 3), indicating that the depo-center of this region was located in the upper sub-reach. However, both sub-reaches experienced erosion during 2007-2011 and 2011-2014 (with higher runoff intensities) (Table 3), implying that the depo-center 
moved into the channel downstream of this region. Moreover, because runoff intensity during 2007-2011 was higher than during 2011-2014, the erosion rates of the two subreaches during 2007-2011 were larger than during 2011-2014, and the erosion rate in the upper sub-reach was larger than in the lower sub-reach during 2007-2011 (Table 3). This suggested that the depo-center moved further downstream during 2007-2011 than 2011-2014. Due to the likely impacts of regulation projects in the Fujiangsha Waterway (Fig. 1(b); Xu et al., 2014), the depo-center in the south branch did not exhibit the reverse behavior (Table 3).

The depositional rate in the lower sub-reach of the middle branch of Rugaosha Waterway was larger than in its upper sub-reach during 2005-2007 (Table 3), indicating that the depo-center was located in the lower sub-reach. During 2007-2011, both subreaches underwent erosion (Table 3), implying that the depo-center was located in the channel downstream of the middle branch. However, the erosional rate in the upper sub-reach was smaller than in the lower sub-reach during 2007-2011 (Table 3). This suggests that the downstream movement of the depo-center was eased by an upstream transport of sediment (eroded from the lower sub-reach during flood-tide) into the upper sub-reach during this flood period. The runoff intensity from 2011 to 2014 had a value between those during 2005-2007 and 2007-2011, and so the position of the depo-center (reflected by the erosion-deposition rates of the two sub-reaches, Table 3) occupied an intermediate location. The depo-center in the Liuhaisha branch exhibited almost the opposite behavior. Both sub-reaches of the Liuhaisha branch experienced deposition during 2005-2007 and erosion during 2007-2011 and 2011-2014 (Table 3), suggesting 
that the depo-center was located in the Liuhaisha branch during the former period but in the channel downstream of the Liuhaisha branch during the latter two periods. In short, the depo-center migrated downstream from 2005 to 2014. Meanwhile, the decrease in erosional rate of the upper sub-reach was larger than that of the lower subreach from 2007-2011 to 2011-2014 as runoff intensity fell (Table 3), indicating upstream migration of the depo-center.

Both sub-reaches of the east branch of the Tongzhousha Waterway experienced erosion during 2007-2011 (Table 3), corresponding to the depo-center being located in the channel downstream of the east branch. However, the erosional rate in the upper sub-reach was smaller than in the lower sub-reach (Table 3). This meant that erosion in the upper sub-reach was relieved by upstream transport of sediment (eroded from the lower sub-reach by the flood-tide) into the upper sub-reach. During 2005-2007 and 2011-2014, the upper and lower sub-reaches underwent erosion and deposition (Table 3), implying that the depo-center was located in the lower sub-reach. In the west branch, the upper and lower sub-reaches respectively experienced erosion and deposition during 2005-2007 (Table 3), indicating that the depo-center was located in the lower sub-reach. However, both sub-reaches experienced erosion during 2011-2014, with the erosional rate of the upper sub-reach increasing significantly (Table 3), as the depocenter moved into the channel downstream of the west branch.

During 2005-2007, the upper and lower sub-reaches of the east branch of the Langshansha Waterway experienced erosion and deposition, respectively (Table 3), with the depo-center accordingly located in the lower sub-reach. During 2007-2011 and 
402 2011-2014, the upper sub-reach accreted sediment, whilst the lower sub-reach 403 underwent deposition (during 2007-2011) followed by erosion (during 2011-2014) 404 (Table 3), meaning that the depo-center moved upstream, even entering the upper sub405 reach. The upper and lower sub-reaches of the west branch experienced deposition and 406 erosion respectively during 2005-2007 and 2011-2014 (Table 3) when the depo-center 407 was located in the upper sub-reach. However, the upper and lower sub-reach underwent 408 erosion and deposition respectively during 2007-2011 (Table 3), as the depo-center 409 migrated downstream in the lower sub-reach during this flood period. 
410 Table 3 Erosional/depositional rates (deposition positive-valued, and erosion negative-valued) for upper and lower sub-reaches of the branching channels at the near411 estuary reach of the Yangtze River over different periods and corresponding multi-year average duration days of different runoff discharges at Datong station

\begin{tabular}{|c|c|c|c|c|c|c|c|c|}
\hline \multirow{2}{*}{ Waterway } & \multirow{2}{*}{$\begin{array}{c}\text { Branching } \\
\text { channel }\end{array}$} & \multirow{2}{*}{ Period } & \multirow{2}{*}{$\begin{array}{c}\text { Erosional/Depositional rate of } \\
\text { upper sub-reach } /\left(\mathrm{m} \cdot \mathrm{yr}^{-1}\right)^{\text {a) }}\end{array}$} & \multirow{2}{*}{$\begin{array}{l}\text { Erosional/Depositional rate of } \\
\left.\text { lower sub-reach/(m-yr }{ }^{-1}\right)^{\text {a) }}\end{array}$} & \multicolumn{4}{|c|}{$\begin{array}{l}\text { Annual mean duration days of runoff discharges at } \\
\left.\text { Datong station/(days } \cdot \mathrm{yr}^{-1}\right)^{\mathrm{b})}\end{array}$} \\
\hline & & & & & $\begin{array}{l}<10,000 \\
\mathrm{~m}^{3} \cdot \mathrm{s}^{-1}\end{array}$ & $\begin{array}{c}10,000-20,000 \\
\mathrm{~m}^{3} \cdot \mathrm{s}^{-1}\end{array}$ & $\begin{array}{c}>50,000 \\
\mathrm{~m}^{3} \cdot \mathrm{s}^{-1}\end{array}$ & $\begin{array}{c}>60,000 \\
\mathrm{~m}^{3} \cdot \mathrm{s}^{-1}\end{array}$ \\
\hline \multirow{6}{*}{ Fujiangsha } & \multirow{3}{*}{$\begin{array}{l}\text { north } \\
\text { region }\end{array}$} & $\begin{array}{l}2005- \\
2007\end{array}$ & 1.083 & 0.212 & 4 & 170 & 10 & 0 \\
\hline & & $\begin{array}{l}2007- \\
2011\end{array}$ & -0.553 & -0.359 & 0 & 168 & 14 & 7 \\
\hline & & $\begin{array}{l}2011- \\
2014\end{array}$ & -0.170 & -0.211 & 0 & 156 & 14 & 0 \\
\hline & \multirow{3}{*}{$\begin{array}{l}\text { south } \\
\text { branch }\end{array}$} & $\begin{array}{l}2005- \\
2007\end{array}$ & 0.802 & -1.331 & 4 & 170 & 10 & 0 \\
\hline & & $\begin{array}{l}2007- \\
2011\end{array}$ & -0.481 & -0.087 & 0 & 168 & 14 & 7 \\
\hline & & $\begin{array}{l}2011- \\
2014\end{array}$ & 0.089 & -0.131 & 0 & 156 & 14 & 0 \\
\hline \multirow{6}{*}{ Rugaosha } & \multirow{3}{*}{$\begin{array}{l}\text { middle } \\
\text { branch }\end{array}$} & $\begin{array}{l}2005- \\
2007\end{array}$ & 0.091 & 0.820 & 4 & 170 & 10 & 0 \\
\hline & & $\begin{array}{l}2007- \\
2011\end{array}$ & -0.383 & -1.023 & 0 & 168 & 14 & 7 \\
\hline & & $\begin{array}{r}2011- \\
2014 \\
\end{array}$ & -0.543 & 0.635 & 0 & 156 & 14 & 0 \\
\hline & \multirow{3}{*}{$\begin{array}{l}\text { Liuhaisha } \\
\text { branch }\end{array}$} & $\begin{array}{l}2005- \\
2007\end{array}$ & 0.487 & 1.437 & 4 & 170 & 10 & 0 \\
\hline & & $\begin{array}{l}2007- \\
2011\end{array}$ & -0.203 & -0.308 & 0 & 168 & 14 & 7 \\
\hline & & $\begin{array}{r}2011- \\
2014 \\
\end{array}$ & -0.038 & -0.265 & 0 & 156 & 14 & 0 \\
\hline \multirow[t]{2}{*}{ Tongzhousha } & \multirow{2}{*}{$\begin{array}{c}\text { east } \\
\text { branch }\end{array}$} & $\begin{array}{l}2005- \\
2007\end{array}$ & -0.229 & 0.708 & 4 & 170 & 10 & 0 \\
\hline & & $2007-$ & -0.113 & -0.172 & 0 & 168 & 14 & 7 \\
\hline
\end{tabular}




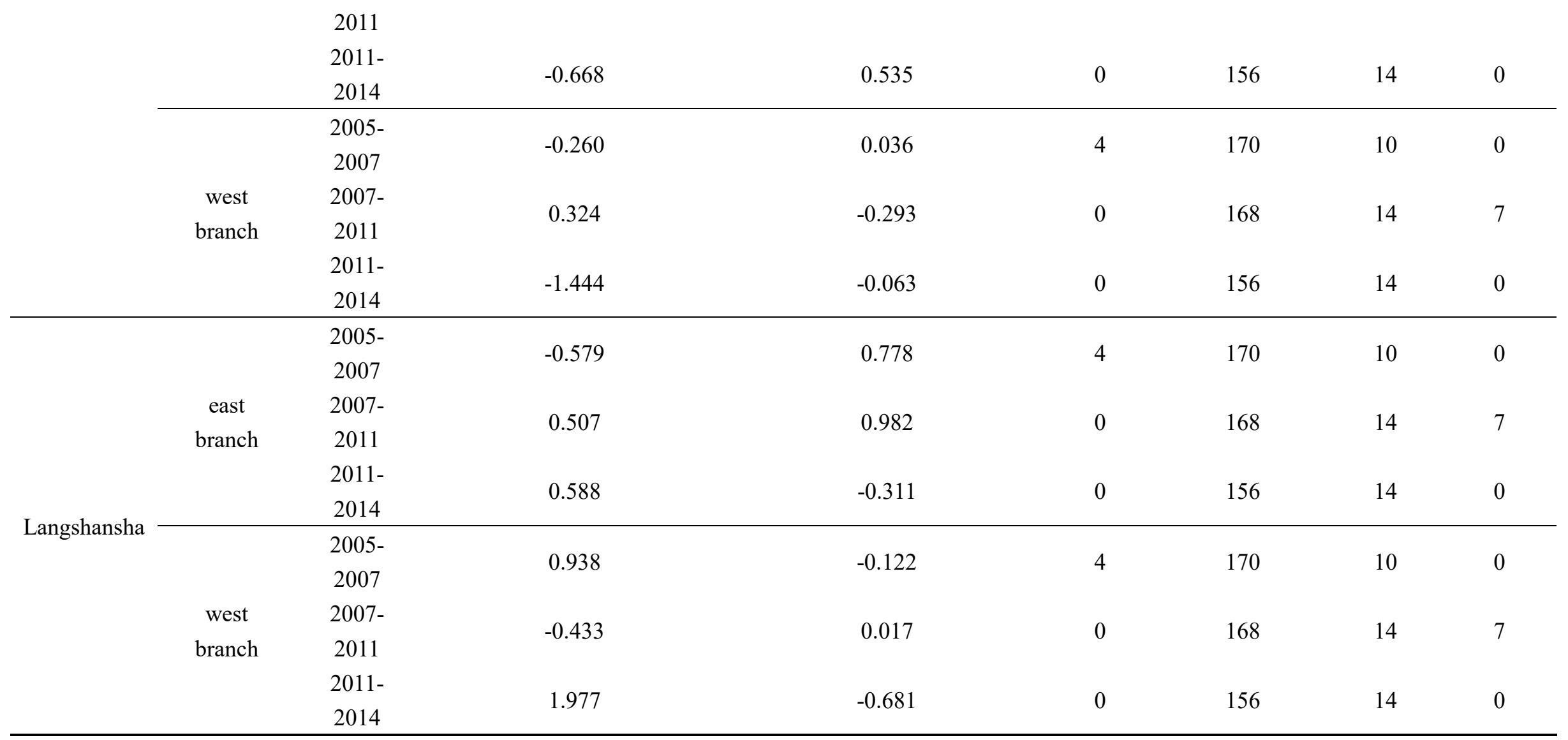

412 a) Fig. 2 shows boundaries of upper and lower sub-reaches of the branching channels.

413 b) $<10,000 \mathrm{~m}^{3} / \mathrm{s}, 10,000-20,000 \mathrm{~m}^{3} / \mathrm{s}$ and $>50,000 \mathrm{~m}^{3} / \mathrm{s}$ are the discharge levels experiencing obvious changes in duration days over periods (Fig. 3), whereas 60,000

$414 \mathrm{~m}^{3} / \mathrm{s}$ approximates the bed-forming discharge in the near-estuary reach of the Yangtze River (Yun, 2004). 


\section{Discussion}

416

417

418

419

420

421

422

423

424

425

5.1 Linkage-mode between channel erosion-deposition and depo-center movement

Through the foregoing analysis, a linkage-mode can be identified between the erosion-deposition patterns of branching channels and their depo-center movements. That is, as a channel experiences erosion/deposition, its depo-center tends to move downstream/upstream. In the north part of Fujiangsha Waterway, the Liuhaisha branch of Rugaosha Waterway, the west branch of Tongzhousha Waterway, and the west branch of Langshansha Waterway, erosion and concomitant downstream depo-center migration occur as runoff intensity increases, whereas deposition and accompanying upstream depo-center migration occur as runoff intensity falls (Table 2; Fig. 7; Table 3). In other branches of the waterways, the two cases of erosion-deposition behavior and concomitant depo-center migration occur as runoff intensity falls and rises, respectively (Table 2; Fig. 7; Table 3).

5.2 Mechanism behind the linkage-mode

Fig. 5 indicates that there is a robust relationship between ebb partition ratio and runoff discharge for a branching channel in the near-estuary reach, given that the morphological changes in the river bed are small, owing to the short timespan from the wet period $\left(30^{\text {th }}\right.$ August to $10^{\text {th }}$ September 2004$)$ to the dry period $\left(17^{\text {th }}\right.$ January to $12^{\text {th }}$ February 2005), and because runoff intensity was weak during this water-recession timespan. The relationships in Fig. 5 are driven by the geographic features of the nearestuary reach. Several raised nodes (formed by mountains) exist along the south bank at the entrance of Fujiangsha Waterway (Chen et al., 1988). These nodes tend to drive 
the ebb tidal current into the north region of Fujiangsha Waterway, with this effect strengthening as runoff intensity rises (Chen et al., 1988). Hence, a high runoff discharge corresponds to a high value of ebb partition ratio in the north region and a low value of ebb partition ratio in the south branch, with the reverse occurring for a low runoff discharge (Figs. 5(a-b)). The Liuhaisha branch of Rugaosha Waterway is much wider than the middle branch of Rugaosha Waterway and connects with the north region of Fujiangsha Waterway (Fig. 1(b)). Hence, a high runoff discharge also facilitates diversion of the ebb tidal current into the Liuhaisha branch while restraining diversion of the ebb tidal current into the middle branch (Figs. 5(c-d); Chen et al., 2012). Given that the cross-section and water depth of the east branch of Tongzhousha Waterway are much larger than those of the west branch (Fig. 1(b)), the ebb tidal current tends to flow into the east branch when the runoff discharge is low, which increases the ebb partition ratio in the east branch and decreases the ebb partition ratio in the west branch (Figs. 5(e-f)). Conversely, the tidal level rises as runoff discharge increases, causing part of the ebb tidal current to divert into the west branch (Chen et al., 2012), leading to the ebb partition ratio exhibiting opposite behavior in the two branches (Figs. 5(e-f)). Given that the two branches of Langshansha Waterway connect directly with those of Tongzhousha Waterway (Fig. 1(b)), the relationships between ebb partition ratio and runoff discharge of the branches are similar to those for the Tongzhousha Waterway (Figs. 5(g-h)).

In the near-estuary reach, the ebb tidal flow consists of runoff discharge and the flood tidal current, both of which are relatively stable at the yearly time scale (Zhu et 
al., 2017, 2018). Consequently, the yearly ebb tidal flow is also stable, implying that ebb partition ratios in the branching channels determine the allocation of ebb tidal amplitudes among these channels. Existing theory has established that the ebb tidal force dominates channel evolution in tide-affected reaches (Dou, 1964). Hence, the ebb partition ratio is responsible for morphological change in a branching channel. During a dry period with low runoff intensity (e.g. 2005-2007), the values of ebb partition ratio (i.e. ebb tidal force) for the south branch of Fujiangsha Waterway, the middle branch of Rugaosha Waterway, the east branch of Tongzhousha Waterway, and the east branch of Langshansha Waterway were large (Figs. 5(b, c, e, g)). Hence, downstream transport of sediment tended to occur in these channels, resulting in erosion or reduced deposition in the channels (Table 2); meanwhile, the channel depo-centers were pushed downstream by the strong ebb tidal current (Table 3). Conversely, the values of ebb partition ratio for other waterway branches were small (Figs. 5(a, d, f, h)), which promoted the relative strength of the flood tide in these channels, driving upstream sediment transport from downstream reaches into the channels, leading to deposition or reduced erosion (Table 2); simultaneously, the channel depo-centers were pushed upstream by the strong flood tidal current (Table 3). During flood periods of high runoff intensity (e.g. 2007-2011 and 2011-2014), the opposite occurred (Fig. 5; Table 2; Table $3)$.

5.3 Trends in channel erosion-deposition and depo-center movement The presence of dams caused decreases in duration days of discharges exceeding $50,000 \mathrm{~m}^{3} / \mathrm{s}$ and $60,000 \mathrm{~m}^{3} / \mathrm{s}$ and increases in duration days of discharges in the range 
481

482

483

$10,000-20,000 \mathrm{~m}^{3} / \mathrm{s}$ (Fig. 3). This resulted in decreasing trends in ebb partition ratios for the north region of Fujiangsha Waterway, the Liuhaisha branch of Rugaosha Waterway, the west branch of Tongzhousha Waterway, and the west branch of Langshansha Waterway, and increasing trends for the other waterway branches (Fig. 4). Accordingly, a branching channel with decreasing ebb partition ratio presented a declining trend, and vice versa (Fig. 6; Chen et al., 2016). Meanwhile, depo-centers in declining branches tended to migrate upstream and become located in the upper subreaches, whereas those in developing branches tended to move downstream into the lower sub-reaches, as demonstrated for recent channel-regulation projects (Wu et al., 2013; Yang and Lin, 2013; Ni et al., 2014).

At the time of writing, a cascade of large dams is being constructed along the upper Yangtze, which will continue to flatten the intra-annual distribution of runoff discharge (Duan et al., 2016). In addition, the future change in climate will help promote this kind of runoff flattening (Cao et al., 2011; Sun et al., 2013; Zeng et al., 2013; Chai et al., 2019). Consequently, recent trends in ebb partition ratios, patterns of channel erosiondeposition, and depo-center movements in the near-estuary reach of the Yangtze are likely to persist well into the future.

\section{Conclusions}

The north region of Fujiangsha Waterway, the Liuhaisha branch of Rugaosha Waterway, the west branch of Tongzhousha Waterway, and the west branch of Langshansha Waterway in the near-estuary reach of the Yangtze River tend to experience increased deposition or reduced erosion in periods of low runoff intensity, 
503

504

505

and vice versa. The depo-centers in these channels have been found to move upstream and downstream under low and high runoff intensity scenarios. Meanwhile, the other waterway branches in the near-estuary reach experience opposite trends in erosiondeposition pattern and depo-center movement with varying runoff intensity.

The mechanism behind the foregoing morphological changes relates to variations in ebb partition ratio in the branching channels as the flow hydrodynamics alters, owing partly to geographic features (raised nodes and connections among the branches) of the near-estuary reach. As runoff discharge rose, the ebb partition ratios in the north region of Fujiangsha Waterway, the Liuhaisha branch of Rugaosha Waterway, the west branch of Tongzhousha Waterway, and the west branch of Langshansha Waterway increased. Thus, sediment in these branching channels tended to be transported into downstream reaches by the ebb tidal current, resulting in erosion or reduced deposition, with the depo-centers pushed downstream. Ebb partition ratios in the other waterway branches decreased, with sediment in downstream reaches transported into the branches by the relatively stronger flood tidal current, leading to deposition or less erosion in the branches, and causing the depo-centers to migrate upstream. As runoff discharge fell, the opposite occurred.

The runoff-flattening effect of dams in Yangtze Basin has greatly decreased the duration days of flood discharges exceeding $50,000 \mathrm{~m}^{3} / \mathrm{s}$ and $60,000 \mathrm{~m}^{3} / \mathrm{s}$, and increased those of the middle-low discharge between 10,000 and $20,000 \mathrm{~m}^{3} / \mathrm{s}$. This in turn significantly reduced the values of ebb partition ratio in the north region of Fujiangsha Waterway, the Liuhaisha branch of Rugaosha Waterway, the west branch of 
Tongzhousha Waterway, and the west branch of Langshansha Waterway. Therefore, these branching channels have presented declining morphological trends, with their depo-centers tending to move upstream, becoming located in the upper sub-reaches. Dam-induced runoff flattening has enhanced ebb partition ratios in the other waterway branches, promoting morphological development and downstream migration of depocenters into the lower sub-reaches of the branches. As a cascade of large dams continues to be constructed along the upper Yangtze and climate change is ongoing, current overall trends in the evolution of branching channels and migration of depo-centers are likely to be maintained into the future.

Although the current study has mainly focused on a local tide-affected braided reach of the Yangtze River, it may be instructive for other braided rivers experiencing similar hydrodynamic processes, because of its representativeness in investigating the morphological evolution in intermediate zones between the fluvial and the estuarine areas. A numerical model, which gives a full consideration of water, sediment and engineering projects, will be set up in the next step to quantify the morphological evolution of this reach.

Acknowledgements This research was supported by open funding of the Key Laboratory of WaterSediment Sciences and Water Disaster Prevention of Hunan Province (No. 2019SS06), and the National Key Research and Development Program of China (No. 2018YFC0407201 and No. 2016YFC0402306).

\section{Reference}

Alcayaga H, Palma S, Caamano D, Mao L, Soto-Alvarez M (2019). Detecting and quantifying 
hydromorphology changes in a Chilean river after 50 years of dam operation. Journal of South American Earth Sciences, 93: 253-266

Cao L J, Zhang Y, Shi Y (2011). Climate change effect on hydrological processes over the Yangtze River basin. Quaternary International, 244(2): 202-210

Chai Y F, Li Y T, Yang Y P, Zhu B Y, Li S X, Xu C, Liu C C (2019). Influence of climate variability and reservoir operation on streamflow in the Yangtze River. Scientific Reports, 9: 5060

Changjiang Water Resources Commission (CWRC) (2016). Changjiang River Sediment Bulletin. Wuhan: Changjiang Press (in Chinese)

Chen J Y, Shen H T, Yun C X, eds (1988). Processes of Dynamics and Geomorphology of the Changjiang Estuary. Shanghai: Shanghai Scientific \& Technical Publishers (in Chinese)

Chen Y P, Jiang N L, Zhang C K (2012). Riverbed evolution of upper part of Yangtze Estuary and its response to the hydrodynamic changes at upstream. In: Proceedings of the $33^{\text {rd }}$ International Conference on Coastal Engineering. Reston: ASCE Press, 1-6

Chen Y P, Li J X, Wu Z G, Pan S Q (2016). Dynamic analysis of riverbed evolution: Chengtong Reach of Yangtze Estuary. Journal of Coastal Research, 75: 203-207

Dai W H, Ding W (2019). Hydrodynamic improvement of a goose-head pattern braided reach in lower Yangtze River. Journal of Hydrodynamics, 31(3): 614-621

Dou G R (1964). The bed form of the alluvial streams and the tidal delta. SHUILI XUEBAO, 1964 : 1-13 (in Chinese)

Duan W X, Guo S L, Wang J, Liu D D (2016). Impact of cascaded reservoirs group on flow regime in the middle and lower reaches of the Yangtze River. Water, 8(6): 218

Fan Y Y, Li Y T, Yang Y P, Huang L B (2017). Vertical velocity structure distribution in the Sansha 
Graf W L (2006). Downstream hydrologic and geomorphic effects of large dams on American rivers.

Han J Q, Zhang W, Yuan J, Fan Y Y (2018). Channel evolution under changing hydrological regimes in anabranching reaches downstream of the Three Gorges Dam. Frontiers of Earth Science, 12(3): $640-648$

Horrevoets A C, Savenije H H G, Schuurman J N, Graas S (2004). The, influence of river discharge on tidal damping in alluvial estuaries. Journal of Hydrology, 294(4): 213-228

Jain V, Sinha R (2004). Fluvial dynamics of an anabranching river system in Himalayan foreland basin, Baghmati river, north Bihar plains, India. Geomorphology, 60(1-2): 147-170

Jansen J D, Nanson G C (2010). Functional relationships between vegetation, channel morphology, and flow efficiency in an alluvial (anabranching) river. Journal of Geophysical Research - Earth

Jiang C J, Li J F, de Swart H E (2012a). Effects of navigational works on morphological changes in Surface, 115: F04030 the bar area of the Yangtze Estuary. Geomorphology, 139: 205-219

Jiang N L, Chen Y P, Zhang C K (2012b). Channel evolution of Chengtong reach at Yangtze Estuary. In: Proceedings of the $22^{\text {nd }}(2012)$ International Offshore and Polar Engineering Conference. San Francisco: ISOPE Press, 1382-1386

Kaliraj S, Chandrasekar N, Magesh N S (2014). Impacts of wave energy and littoral currents on shoreline erosion/accretion along the south-west coast of Kanyakumari, Tamil Nadu using DSAS and geospatial technology. Environmental Earth Sciences, 71(10): 4523-4542 
591

592

593

594

595

596

597

598

599

600

601

602

603

604

605

606

607

608

609

610

611

612

upper reach of the deepwater navigation channel in the Yangtze Estuary. Journal of Hydrodynamics, 26(2): 299-308

Latrubesse E M (2008). Patterns of anabranching channels: The ultimate end-member adjustment of mega rivers. Geomorphology, 101(1-2): 130-145

Li M T, Chen Z Y, Yin D W, Chen J, Wang Z H, Sun Q L (2011). Morphodynamic characteristics of the dextral diversion of the Yangtze River mouth, China: tidal and the Coriolis Force controls. Earth Surface Processes and Landforms, 36(5): 641-650

Li M T, Ge J Z, Kappenberg J, Much D, Nino O, Chen Z Y (2014). Morphodynamic processes of the Elbe River estuary, Germany: the Coriolis effect, tidal asymmetry and human dredging. Frontiers of Earth Science, 8(2): 181-189

Li Z W, Yu G A, Brierley G, Wang Z Y (2016). Vegetative impacts upon bedload transport capacity and channel stability for differing alluvial planforms in the Yellow River source zone. Hydrology and Earth System Sciences, 20(7): 3013-3025

Liu F, Hu S, Guo X J, Luo X X, Cai H Y, Yang Q S (2018). Recent changes in the sediment regime of the Pearl River (South China): Causes and implications for the Pearl River Delta. Hydrological Processes, 32(12): 1771-1785

Luan H L, Ding P X, Wang Z B, Ge J Z, Yang S L (2016). Decadal morphological evolution of the Yangtze Estuary in response to river input changes and estuarine engineering projects. Geomorphology, 265: 12-23

Mendoza A, Soto-Cortes G, Priego-Hemandez G, Rivera-Trejo F (2019). Historical description of the morphology and hydraulic behavior of a bifurcation in the lowlands of the Grijalva River Basin, Mexico. Catena, 176: 343-351 
613

614

615

616

617

618

619

620

621

622

623

624

625

626

627

628

629

630

631

632

633

634

Ni B, He R, Zhang W (2014). Study on dredging scale of Tongzhousha west channel. Journal of Waterway and Harbor, 35(6): 608-612 (in Chinese)

Petts G E, Gurnell A M (2005). Dams and geomorphology: Research progress and future directions. Geomorphology, 71(1-2): 27-47

Rangoonwala A, Jones C E, Ramsey E (2016). Wetland shoreline recession in the Mississippi River Delta from petroleum oiling and cyclonic storms. Geophysical Research Letters, 43(22): 1165211660

Schletterer M, Shaporenko S I, Kuzovlev V V, Minin A E, Van Geest G J, Middelkoop H, Gorski K (2019). The Volga: Management issues in the largest river basin in Europe. River Research and Applications, 35(5): 510-519

Shen Y M, Deng G F, Xu Z H, Tang J (2019). Effects of sea level rise on storm surge and waves within the Yangtze River Estuary. Frontiers of Earth Science, 13(2): 303-316

Sloff K, Van Spijk A, Stouthamer E, Sieben A (2013). Understanding and managing the morphology of branches incising into sand-clay deposits in the Dutch Rhine Delta. International Journal of Sediment Research, 28(2): 127-138

Sun J L, Lei X H, Tian Y, Liao W H, Wang Y H (2013). Hydrological impacts of climate change in the upper reaches of the Yangtze River Basin. Quaternary International, 304: 62-74

Wang Y H, Dong P, Oguchi T, Chen S L, Shen H T (2013). Long-term (1842-2006) morphological change and equilibrium state of the Changjiang (Yangtze) Estuary, China. Continental Shelf Research, 56: 71-81

Warne A G, Guevara E H, Aslan A (2002). Late Quaternary evolution of the Orinoco Delta, Venezuela. Journal of Coastal Research, 18(2): 225-253 
635

636

637

638

639

640

641

642

643

644

645

646

647

648

649

650

651

652

653

654

655

656

Wu Z G, Chen Y P, Zhang C K, Jiang N L (2013). Fluvial dynamic analysis of Rugaosha reach in Changjiang Estuary. Yangtze River, 44(24): 13-16+19 (in Chinese)

Xu Y, Gong H F, Zhang H (2014). Study on branch selection for $12.5 \mathrm{~m}$ - deep main channel in Fujiangsha reach downstream the Changjiang River. Port \& Waterway Engineering, 2014(5): 17 (in Chinese)

Yang S L, Milliman J D, Li P, Xu K (2011). 50,000 dams later: Erosion of the Yangtze River and its delta. Global and Planetary Change, 75(1-2): 14-20

Yang S L, Xu K H, Milliman J D, Yang H F, Wu C S (2015). Decline of Yangtze River water and sediment discharge: Impact from natural and anthropogenic changes. Scientific Reports, 5: 12581

Yang X W, Lin Q (2013). Evolution analysis and maintenance countermeasures of north channel of Fujiang shoal in Lower Yangtze River. Journal of Waterway and Harbor, 34(1): 50-54 (in Chinese)

Yu W C, eds (2013). Understanding and Practice of the Yangtze River. Beijing: China Water \& Power Press (in Chinese)

Yun C X, eds (2004). Recent Developments of the Changjiang Estuary. Beijing: China Ocean Press (in Chinese)

Zeng X F, Zhao N, Zhou J Z (2013). Study on hydropower energy and its future changes in the upper Yangtze River basin under climate change. Advanced Research on Material, Energy and Control Engineering, 648: 232-236

Zhang W, Xu P (2017). Morphological relationships of runoff tidal estuary on the lower reaches of the Yangtze River. China Harbour Engineering, 37(1): 19-23 (in Chinese) 
657

658

659

660

661

662

663

664

665

666

667

668

669

670

671

672

673

674

675

676

677

678

Zhang W, Xu Y, Hoitink A J F, Sassi M G, Zheng J H, Chen X W, Zhang C (2015). Morphological change in the Pearl River Delta, China. Marine Geology, 363: 202-219

Zhao J, Guo L C, He Q, Wang Z B, van Maren D S, Wang X Y (2018). An analysis on half century morphological changes in the Changjiang Estuary: Spatial variability under natural processes and human intervention. Journal of Marine Systems, 181: 25-36

Zheng S W, Cheng H Q, Shi S Y, Xu W, Zhou Q P, Jiang Y H, Zhou F N, Cao M X (2018). Impact of anthropogenic drivers on subaqueous topographical change in the Datong to Xuliujing reach of the Yangtze River. Science China - Earth Sciences, 61(7): 940-950

Zhou Y Y, Huang H Q, Ran L S, Shi C X, Su T (2018). Hydrological controls on the evolution of the Yellow River Delta: An evaluation of the relationship since the Xiaolangdi Reservoir became fully operational. Hydrological Processes, 32(24): 3633-3649

Zhu B Y, Deng J Y, Yue Y, Li Z W, Zhang C C (2019). Responses of erosion and deposition in braided reaches between Datong and Jiangyin to varying water and sediment discharges in lower Yangtze River. Taiwan Water Conservancy, 67(2): 46-57 (in Chinese)

Zhu B Y, Li Y T, Yang P Y, Deng J Y, Yang Y P, Li S X (2018). River bed erosion and deposition responses to sediment reduction in the Chengtong reach of the Yangtze River. Advances in Water Science, 29(5): 706-716 (in Chinese)

Zhu B Y, Li Y T, Yue Y, Yang Y P (2017). Aggravation of north channels' shrinkage and south channels' development in the Yangtze Estuary under dam-induced runoff discharge flattening. Estuarine Coastal and Shelf Science, 187: 178-192

\section{Author biographies}

口 Boyuan ZHU 
Water Conservancy and Hydropower Engineering, B.S., Wuhan University, Wuhan,

680 China, 2011

681 Hydraulics and River Dynamics, Ph.D, Wuhan University, Wuhan, China, 2017

682 Dr. Zhu served as a technical professional in Zhongnan Engineering Corporation

683 Limited of Power China during 2017-2018, before taking up a teaching position at

684 Changsha University of Science \& Technology from 2018. His research interests

685 include sediment transport and river evolution.

686 The email address of Dr. Zhu is: boyuan@csust.edu.cn

$687 \square$ Jinyun DENG

688 Port, Channel and River Regulation, B.S., Wuhan University, Wuhan, China, 1998

689 Hydraulics and River Dynamics, M.S., Wuhan University, Wuhan, China, 2000

690 Hydraulics and River Dynamics, Ph.D, Wuhan University, Wuhan, China, 2003

691 Prof. Deng gained a teaching position in Wuhan University in 2003 and was

692 appointed associate professor in 2006. His research interests include sediment

693 transport and river evolution.

694 The email address of Prof. Deng is: dengjinyun@whu.edu.cn

$695 \square$ Jinwu TANG

696 Port, Channel and River regulation, B.S., Wuhan University, Wuhan, China, 2007

697 Hydraulics and River Dynamics, Ph.D, Wuhan University, Wuhan, China, 2012

698 Dr. Tang is a technical professional in Changjiang Institute of Survey, Planning,

699 Design and Research, where he has been employed since 2012. His research 700 interests include river planning and management. 
702

Wenjun YU

Water Conservancy and Hydropower Engineering, B.S., Xi'an University of Technology, Xi'an, China, 2012

Hydraulics and River Dynamics, M.S., Wuhan University, Wuhan, China, 2015 Mr. Yu is a technical professional in Changjiang Waterway Institute of Planning, Design \& Research, where he has been employed since 2015. His research interests include river regulation and management.

The email address of Mr. Yu is: y430011@sina.cn

ㅁ Alistair G.L. BORTHWICK

Civil engineering, BEng (1st class), University of Liverpool, Liverpool, UK, 1978 PhD, University of Liverpool, Liverpool, UK, 1982

MA, University of Oxford, Oxford, UK, 1990

DSc, University of Oxford, Oxford, UK, 2007

Prof. Borthwick was previously professor of engineering science at the University of Oxford, where he worked for 21 years from 1990-2011. He is presently a professorial fellow at the University of Edinburgh. His research interests include coastal and offshore engineering, environmental fluid mechanics, and marine power resource assessment.

Prof. Borthwick has 40 years' engineering, research, and teaching experience. He was elected a Fellow of the Institution of Civil Engineers, FICE, in 2003, a Fellow of the Royal Academy of Engineering, FREng, in 2014, and a Fellow of the Royal 
Society of Edinburgh, FRSE, in 2015.

His email address is: $\underline{\text { Alistair.Borthwick@ed.ac.uk }}$

Agricultural Water Conservancy Engineering, B.S., Taiyuan University of Technology, Taiyuan, China, 2016

Hydraulics and River Dynamics, M.S., Wuhan University, Wuhan, China, 2019

Mr. Chai's research interests include sediment transport and river evolution.

His email address is: 2808676930@qq.com

\section{ㅁ Zhaohua SUN}

Port, Channel and River Regulation, B.S., Wuhan University, Wuhan, China, 1999 Hydraulics and River Dynamics, Ph.D, Wuhan University, Wuhan, China, 2004 Prof. Sun took up a teaching position in Wuhan University in 2004 and has since been appointed associate professor. His research interests include sediment transport and river evolution.

His email address is: Lnszh@126.com

口 Yitian LI

Port, Channel and River Regulation, B.S., Wuhan University, Wuhan, China, 1981 Hydraulics and River Dynamics, Ph.D, Wuhan University, Wuhan, China, 1987 Prof. Li has been employed by Wuhan University for 32 years, where he is senior professor in river engineering. His research interests include sediment transport and river evolution.

Prof. Li is vice director of the Sediment Committee of the Chinese Hydraulic 
